\title{
PENGARUH COWORKER SUPPORT TERHADAP TURNOVER INTENTION MELALUI ORGANIZATIONAL EMBEDDEDNESS PADA PT. BCA KCP KAPAS KRAMPUNG SURABAYA
}

\author{
Rahmadani Nadya Ngestreini \\ Universitas Negeri Surabaya \\ raahmaadaani@gmail.com \\ Budiono Budiono \\ Universitas Negeri Surabaya \\ ec.budiono@unesa.ac.id
}

\begin{abstract}
Working in the financial services sector, such as assurance and banking, can be stressful for employees. However, employees who have organizational attachments and coworkers support will reduce turnover. This investigation intends to analyze the impact of coworker support on turnover intention through organizational embeddedness as an intermediary variable at PT. BCA KCP Kapas Krampung Surabaya. The sampling technique used saturated samples with a total of 34 employees. Data were gathered by conducting interviews and spreading questionnaires to employees, then processed using SmartPLS 3.3.3 software tools. The finding proves that coworker support has a significantly positive effect either on organizational embeddedness and turnover intention. Furthermore, organizational embeddedness also holds a significant and negative influence on turnover intention. This result supported the existing theories based on a thorough analysis of the literature.
\end{abstract}

Keywords: coworker support; organizational embededdness; turnover intention.

\section{PENDAHULUAN}

Indonesia merupakan negara dengan tingkat turnover tertinggi keempat di dunia dengan persentase sebesar 15,8\% (Gutmann, 2016). Selama tiga bulan pertama tahun 2020, terdapat peningkatan klaim biaya hidup masa tua saat sudah tidak bekerja (JHT) di BPJamsostek sebesar 10,02\% dari tahun 2019, sebesar 76,5\% klaim dilakukan untuk pengunduran diri, 17,6\% untuk PHK, kemudian sisanya klaim dari pekerja yang memasuki usia pensiun, meninggal, dan lain-lain (Sari, 2020). Berdasarkan informasi Mercer Talent Consulting \& Information Solution terkait hasil Survei Gaji tahun 2015, turnover talent pada sektor perbankan dinilai sebagai turnover tertinggi dengan tingkat kira-kira sebesar 16 persen (Prahadi, 2015). Hal tersebut didukung lembaga survei Pricewaterhouse Coopers $(\mathrm{PwC})$ bahwa tingkat turnover karyawan pada sektor perbankan di Indonesia mencapai kira-kira lebih tinggi dari sepuluh persen, padahal angka ideal dari tingkat turnover di dalam dunia perbankan hanya sekitar lima persen (Helen, 2014).

Bekerja di sektor jasa keuangan seperti perbankan, dapat membuat para karyawan merasakan stres dan penuh tuntutan, demikian karena mereka seringkali membutuhkan jam kerja yang panjang dan kebutuhan untuk memenuhi deadline yang ketat (Cooke et al., 2019). Dukungan atasan dan rekan kerja sangat penting dalam mengurangi stres dan memengaruhi resiliensi, sehingga karyawan tidak memiliki turnover intention atau niat untuk keluar dari pekerjaannya (Cooke et al., 2019). Demikian karena pekerjaan tidak selalu tentang tugas yang harus dikerjakan, namun individu akan secara aktif mencari teman sebaya untuk bersosialisasi dan menjadikannya rekan kerja (Tews et al., 2018).

Coworker support merupakan dukungan dari rekan kerja yang dapat bertindak sebagai faktor yang dapat mendorong karyawan untuk menetap atau meninggalkan pekerjaannya. Beberapa riset terdahulu yang menjelaskan dukungan dari rekan kerja memiliki pengaruh yang signifikan negatif dibuktikan oleh Hmrd \& Yy (2020), Anisa (2019), De Clercq et al. (2020), dan Self \& Gordon (2019). Berlawanan dengan riset tersebut, Self et al., (2020) membuktikan coworker support tidak berpengaruh signifikan terhadap turnover intention. Hanya jenis coworker support berbeda yang akan 
Rahmadani Nadya Ngestreini \& Budiono Budiono. Pengaruh Coworker Support terhadap Turnover Intention melalui Organizational Embeddedness pada PT. BCA KCP Kapas Krampung Surabaya

berdampak pada turnover intention. Hasil tersebut didukung Tews et al., (2013) dan Tews et al., (2019).

Coworker support juga dipandang sebagai salah satu sumber daya yang memberikan dampak pada organizational embeddedness, terutama bagi karyawan muda yang menghargai persahabatan melalui pekerjaan (Tews et al., 2013). Organizational embeddedness merupakan keterlekatan yang dirasakan karyawan pada organisasi tempat karyawan bekerja. Semakin besar coworker support yang dirasakan karyawan dalam lingkungan kerja, maka akan semakin besar organizational embeddedness pada diri karyawan (Self et al., 2020). Beberapa riset terdahulu yang mendukung pernyataan tersebut yaitu Self \& Gordon (2019) dan Karatepe (2016).

Penelitian ini menggunakan sub-dimensi dari job embeddedness, yaitu organizational embeddedness. Job embeddedness pada dasarnya menyematkan individu dalam organisasi, sehingga dianggap pula menyiratkan organizational embededdnes. Oleh karena itu, menurut Peltokorpi et al. (2014), istilah job embeddedness dan organizational embeddedness dianggap sebagai frasa yang bermakna sama.

Keterlekatan karyawan akan mengarah pada penurunan turnover intention (Self et al., 2020). Ketika dihadapkan dengan hal-hal negatif di lingkungan kerja, hubungan interpersonal yang berkualitas tinggi akan berfungsi sebagai penyangga untuk membantu dan memastikan para karyawan tetap bersama organisasi (Tews et al., 2013). Karyawan yang memiliki keterlekatan tinggi biasanya cenderung tidak ingin meninggalkan organisasi mereka, pernyataan tersebut didukung Huang et al. (2020), Peltokorpi et al. (2014), Dechawatanapaisal (2017), Zakaria \& Astuty (2017), Rarasanti \& Suana (2016), Nguyen (2015), dan Aryani \& Rahardjo (2018). Berlawanan dengan sejumlah riset tersebut, Gunawan \& Azzahra (2017) dan Octavia Asta Maniri (2019) menjelaskan tidak ada pengaruh antara keterlekatan dan niat karyawan untuk keluar pekerjaan.

Penelitian dilakukan di PT. BCA KCP Kapas Krampung Surabaya. Menurut wawancara yang dilakukan pada beberapa karyawan, perusahaan ini sangat percaya bahwa kerja tim yang kuat akan sangat penting untuk mendukung lingkungan kerja yang nyaman dan kondusif. Motto yang dikenalkan pada mereka, yaitu "ONE BCA" yang melambangkan semangat kerja karyawan, sehingga bekerja di BCA serasa bekerja bersama keluarga. Selain itu, BCA terus berupaya meningkatkan kompetensi dan kapabilitas karyawannya dengan memberikan program pelatihan dan pengembangan karir. Kesesuaian antara kebutuhan karir dan nilai-nilai yang dirasakan oleh karyawan organisasi juga sangat baik.

Meskipun dukungan rekan kerja dan keterlekatan organisasi di tempat kerja mereka dinilai baik, terdapat fenomena yang terkait dengan niat keluar. Menurut informasi dari narasumber, beberapa karyawan, terutama karyawan kontrak, seringkali melakukan resign dari perusahaan. Beberapa alasan rekan kerja meninggalkan perusahaan bersifat pribadi seperti ingin berhenti karena menikah, ingin memiliki waktu luang untuk mengurus keluarga, kontrak sudah habis tetapi tidak diperpanjang, atau mendapat pekerjaan baru di perusahaan lain.

Diketahui tahun 2018 hingga 2020 jumlah karyawan yang melakukan pengunduran diri memiliki persentase di atas lima persen. Tahun 2018 sebesar tujuh persen, tahun 2019 sebesar 19\%, dan tahun 2020 sebesar $10 \%$. Berdasarkan tingkat turnover perusahaan di kalangan industri perbankan, nilai tersebut dianggap cukup tinggi. Oleh karena itu, penelitian ini memiliki maksud untuk menyelidiki pengaruh coworker support pada turnover intention yang diintervening organizational embeddedness.

\section{KAJIAN PUSTAKA DAN PENGEMBANGAN HIPOTESIS}

\section{Coworker Support}

Coworker support atau dukungan rekan kerja adalah bentuk interaksi antar rekan di tempat kerja, dengan cara membangun komunikasi yang baik dengan mereka (Umboh, 2015). Tri Wijayati et al. (2020), mengemukakan dukungan rekan kerja adalah bentuk tindakan ketika seseorang berbagi pengetahuan dan keahlian, serta membantu rekan kerja mereka dalam menghadapi tugas-tugas yang 
menantang dalam penyediaan layanan. Selain itu, memberi bantuan kepada orang lain di tempat kerja dan memberi dorongan juga dianggap sebagai dukungan rekan kerja (Hmrd \& Yy, 2020). Wongboonsin et al. (2018), menjelaskan dukungan sosial rekan kerja sebagai kesediaan rekan kerja untuk saling membantu satu sama lain, misalnya seperti menunjukkan sikap peduli, ramah, hangat, empati, kerjasama, tidak ada gossip, tidak ada penghianatan, saling menghargai, saling menghormati dan saling memberi dukungan dalam melaksanakan tugas sehari-hari mereka dalam mengurangi keadaan yang menyusahkan atau mengancam. Dukungan rekan kerja dapat memberikan kontribusi terhadap karir karyawan melalui bimbingan dan informasi karir, pengembangan keterampilan baru, serta persahabatan yang cenderung meningkatkan kepuasan karyawan dengan karir mereka di organisasi saat ini (Karatepe \& Olugbade, 2017).

Menurut Woo \& Chelladurai (2012), dukungan rekan kerja merupakan bagian dari perceived organizatonal support (POS), di mana dukungan organisasi yang dirasakan mencakup dukungan yang berasal dari rekan di tempat kerja, pengawas atau supervisor, serta dukungan lainnya. Sedangkan menurut Bateman (2009, dalam Wongboonsin et al., 2018), dukungan rekan kerja merupakan dimensi dari dukungan sosial atau social support di tempat kerja. Dukungan sosial yang dimaksud berkaitan dengan bantuan yang diberikan oleh rekan kerja ketika seseorang sedang melakukan tugas individu, contohnya seperti berbagi pengetahuan, pengalaman, motivasi, dan dukungan emosional.

\section{Organizational Embeddedness}

Keterlekatan organisasi dapat diartikan sebagai totalitas kekuatan yang terdiri dari links atau keterkaitan, fit atau kesesuaian, dan sacrifice atau pengorbanan ( $\mathrm{Ng} \&$ Feldman, 2007). Maksud link pada entitas dalam organisasi adalah tim rekan kerja, dan link pada entitas dalam komunitas adalah kerabat, teman, dan kelompok sosial (Zhang et al., 2012). Fit merupakan perasaan cocok dengan organisasi dan lingkungan kerja yang melibatkan rencana self-value dan tujuan karir karyawan dengan melakukan penyesuaian dengan budaya organisasi dan pekerjaan, yang mana semakin kuat fit, menandakan semakin besar kepekaan pekerja terhadap kenyamanan dengan perusahaannya (Zainuddin \& Noor, 2019). Sacrifice menurut Mitchell et.al. (2001, dalam Self \& Gordon, 2019), merupakan pengorbanan yang dirasakan dari manfaat psikologis yang mungkin akan hilang apabila meninggalkan pekerjaan.

Penelitian ini menggunakan sub-dimensi dari job embeddedness yaitu organizational embeddedness, sub-dimensi job embeddedness terdiri dari organisasi dan komunitas (Zhang et al., 2012). Menurut Erez et al. (2001, dalam Esterlita \& Purba, 2019), job embeddedness terdiri dari organizational embeddedness, yang didefinisikan sebagai faktor-faktor dalam organisasi yang menghubungkan karyawan dengan organisasi, dan community embeddedness yang didefinisikan sebagai faktor-faktor dalam komunitas karyawan yang mendorong karyawan untuk tetap bersama organisasi. Salah satu alasan memfokuskan penelitian pada organisasi dibandingkan pekerjaan adalah organisasi dan komunitas mewakili sistem sosial, dan menurut definisi, keterlekatan adalah bentuk umum keterikatan pada entitas sosial (Singh et al., 2017). Alasan lainnya, keterlekatan komunitas tidak relevan dengan situasi yang diteliti. Beberapa riset menyatakan bahwa organizational embeddedness dapat lebih baik memprediksi perilaku atau retensi karyawan daripada community embeddedness (Allen, 2006; Lee et al., 2004; Dechawatanapaisal, 2017). Pada dasarnya, job embededdness menyematkan individu dalam organisasi, sehingga dianggap pula menyiratkan organizational embededdnes.

\section{Turnover Intention}

Turnover intention atau intensi keluar merupakan keluarnya karyawan baik dengan kehendak atau kemauannya sendiri maupun tidak sukarela (Suyono et al., 2020). Namun, dapat pula berbentuk iktikad untuk berhenti kerja dengan penarikan diri atas kehendak sendiri atau pemberhentian oleh organisasinya (Rarasanti \& Suana, 2016). Turnover intention hanya sebatas keinginan atau rencana berpindah saja, namun belum berbentuk realisasi turnover sesungguhnya (Octavia Asta Maniri, 2019). Menurut Mathis \& Jackson (2011), turnover intention merupakan suatu kondisi di mana karyawan ingin meninggalkan organisasi dan ingin segera dihentikan. Definisi lainnya yakni keinginan seseorang untuk pindah pekerjaan atau berhenti kerja dari suatu organisasi, dapat disebabkan karena 
rasa tidak nyaman dengan pekerjaan serta ingin mendapatkan pekerjaan yang lebih baik dari pekerjaannya sekarang (Zakaria \& Isthofaina, 2017). Keinginan keluar juga disebut sebagai proses multi-tahap yang melibatkan keluarnya karyawan dari posisi mereka saat ini dipicu oleh tanggapan psikologis secara negatif terhadap organisasi, pekerjaan, dan situasi pekerjaan eksternal terkait dengan sudut pandang pribadi karyawan (Takase, 2010).

Turnover intention karyawan dapat menimbulkan kerugian yang besar bagi perusahaan apabila tidak dilakukan identifikasi dan tindakan cepat untuk mencegah hal tersebut terjadi (Anisa, 2019). Menurut Harnoto (2002, dalam Halimah et al., 2016), beberapa perilaku karyawan yang mengindikasikan turnover ditandai meningkatnya ketidakhadiran karena bolos kerja, malas bekerja, meningkatnya pengingkaran pada tata tertib kerja, dan meningkatnya penentangan pada atasan. Adapun beberapa faktor yang memengaruhi terjadinya niat karyawan untuk keluar dari pekerjaan diantaranya: (1) Organizational commitment, (2) Organizational citizenship behaviors, (3) Organizational justice, dan (4) Perceived organizational support (Woo \& Chelladurai, 2012).

\section{Hubungan antar Variabel}

Mengingat bahwa hubungan sosial adalah inti dari pengalaman sebagian besar individu di tempat kerja, maka dukungan sosial yang dirasakan tiap individu tentu saja memiliki dampak yang cukup besar pada pergantian karyawan (Tews et al., 2019). Faktor organisasi yang memengaruhi retensi / perputaran termasuk gaji yang lebih baik, dukungan supervisor, beban kerja yang wajar, dukungan rekan kerja, peluang untuk kemajuan, komitmen organisasi, dan penilaian karyawan (Williams, 2018). Sejumlah riset pun menunjukkan bahwa karyawan yang merasa dukungan rekan kerjanya baik, dapat meningkatkan retensi dan motivasi mereka di tempat kerja (Naz et al., 2020; Malik \& Malik, 2015; Self et al., 2020).

Penyebab seorang pekerja mengundurkan diri dari suatu perusahaan tentunya didukung berbagai alasan, salah satunya berupa baik atau buruknya dukungan rekan kerja yang dirasakan karyawan. Hubungan rekan kerja yang saling mendukung, akan membantu mengurangi perasaan negatif tentang fungsi organisasi mereka, sehingga akan menurunkan pula turnover intention pada diri karyawan (De Clercq et al., 2020). Karyawan akan menunjukkan turnover intention yang lebih rendah ketika menerima coworker support yang lebih besar (Karatepe, 2012; Tews et al., 2018).

H1: Terdapat pengaruh negatif coworker support terhadap turnover intention.

Coworker support dianggap sebagai salah satu sumber daya yang memengaruhi organizational embeddedness, terutama bagi karyawan muda yang menghargai persahabatan melalui pekerjaan (Tews et al., 2013). Karyawan yang memiliki keterlekatan kerja tinggi cenderung akan memiliki kinerja yang baik karena adanya perasaan dalam hubungan yang menyenangkan (Ayuni \& Etikariena, 2020). Semakin banyak karyawan yang terlekat pada pekerjaan mereka, maka semakin kecil kemungkinan mereka untuk mengundurkan diri, hal ini karena adanya hubungan yang dimiliki karyawan dengan kolega lain dalam organisasi dan atau karena kesesuaian karyawan terhadap organisasi tempat mereka bekerja (Aryani \& Rahardjo, 2018). Ketika dihadapkan dengan hal-hal negatif di lingkungan kerja, hubungan interpersonal yang berkualitas tinggi akan berfungsi sebagai penyangga untuk membantu dan memastikan para karyawan tetap bersama organisasi (Tews et al., 2013). Menurut Felps et al. (2009, dalam Tews et al., 2018), karyawan yang merasa klop dengan profesi dan organisasinya, dapat diperiksa dari bagaimana mereka membangun hubungan dengan orang-orang yang ada di organisasi maupun di luar pekerjaannya, serta apa yang harus mereka korbankan apabila memilih berhenti dari profesi mereka. Menurut Karatepe (2016), karyawan dengan keterlekatan yang tinggi akan terlibat dalam sejumlah tugas dan terikat dengan orang-orang seperti rekan kerja, mereka akan memiliki perasaan yang baik tentang hubungan kerja, serta sadar akan hilangnya manfaat yang akan mereka rasakan apabila terjadi turnover. Apabila dukungan rekan kerja dirasakan baik oleh seseorang, maka mereka akan semakin terlekat dengan organisasinya (Self et al., 2020),

H2: Terdapat pengaruh positif coworker support terhadap organizational embeddedness. 
Faktor lain yang dapat memengaruhi jumlah dan penambahan turnover karyawan yakni keterlekatan kerja (Zakaria \& Astuty, 2017). Keterlekatan karyawan berupaya membentuk eksistensi karyawan dalam menumbuhkan rasa keterlekatan kerja dalam suatu organisasi, namun bukan untuk mengikat mereka untuk terus berkarya dalam organisasinya (Maska \& Riyanto, 2020). Perasaan negatif tentang pekerjaan tidak serta merta menyebabkan pekerja meninggalkan pekerjaannya, apabila keterlekatannya tinggi, maka cenderung tidak ingin meninggalkan organisasi (Huang et al., 2020). Sejalan dengan teori tersebut, Holtom et al. (2008, dalam Peltokorpi et al., 2014) menjelaskan sejumlah penelitian yang telah membuktikan karyawan yang memiliki keterlekatan tinggi akan lebih condong untuk tidak ingin meninggalkan organisasi mereka. Kholiq \& Miftahuddin (2017) yang menguji tiga indikator dari organizational embeddedness, menunjukkan keterlekatan organisasi yang tinggi akan membuat karyawan merasa akan banyak mengorbankan benefit yang mereka terima apabila berhenti dari pekerjaannya

Self et al. (2020) berpendapat bahwa organisasi yang memberikan penghargaan pada tim kerja karena berhasil memenuhi tugas tertentu dapat lebih menonjolkan nilai-nilai coworker support, sehingga dengan demikian akan meningkatkan organizational embeddedness dan mengurangi turnover intention. Menurut Burton et al. (2010, dalam Self et al., 2020), teori keterlekatan pekerjaan pun menyatakan bahwa hubungan karyawan pada organisasi memainkan peran utama dalam keterlekatan seorang karyawan dalam suatu organisasi, jadi semakin besar dukungan rekan kerja yang dirasakan seorang karyawan, semakin besar tingkat keterlekatan organisasi mereka dan semakin rendah pula turnover intention mereka.

H3: Terdapat pengaruh negatif organizational embeddedness terhadap turnover intention.

Keterlekatan telah digunakan sebagai mediator di beberapa riset terdahulu (Self et al., 2020). Salah satu contohnya adalah riset oleh Ghosh et al. (2017), dengan mengaitkan dengan keadilan dan kinerja dalam peran. Contoh lainnya adalah riset oleh Esterlita \& Purba (2019), dengan mengkaitkan dengan hubungan antara peluang karir yang dirasakan dan niat berpindah.. Keterlekatan kerja dapat memprediksi niat keluar secara lebih efektif daripada variabel tradisional seperti komitmen organisasi dan kepuasan kerja (Rarasanti \& Suana, 2016; Huang et al., 2020). Menurut Dechawatanapaisal (2017), seseorang dengan tingkat keterikatan organisasi yang rendah, cenderung memengaruhi rekan kerjanya untuk mempertimbangkan berhenti. Organizational embeddedness diperkirakan mempunyai fungsi mediasi dari pengaruh coworker support pada turnover intention. Dugaan tersebut masuk akal karena selaras dengan pengujian oleh Self et al. (2020), tentang bagaimana dukungan rekan kerja mengurangi keinginan berhenti dari pekerjaan dengan analisis mediasi menggunakan organizational embeddedness.

H4: Organizational embeddedness memediasi pengaruh coworker support terhadap turnover intention.

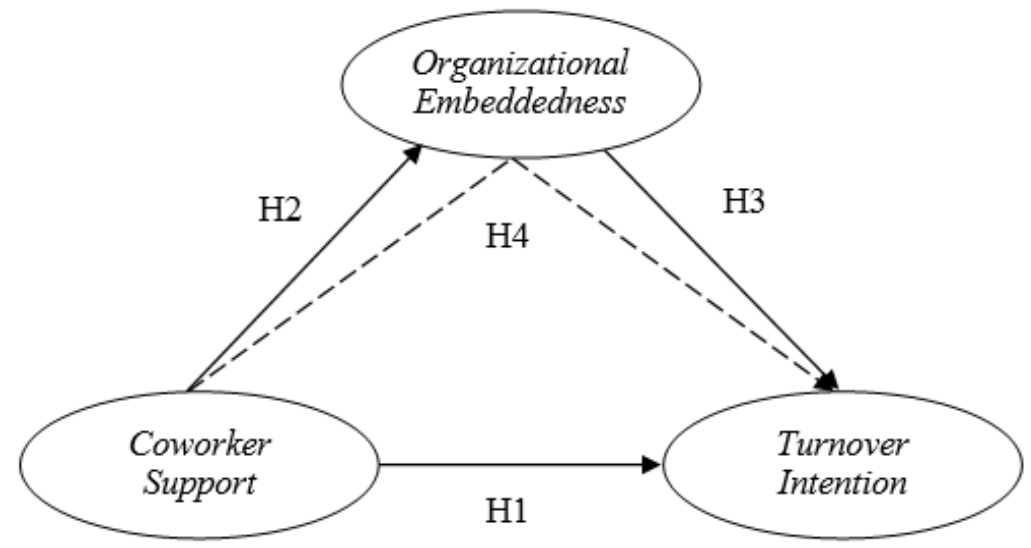

Gambar 1. KERANGKA KONSEPTUAL 
Rahmadani Nadya Ngestreini \& Budiono Budiono. Pengaruh Coworker Support terhadap Turnover Intention melalui Organizational Embeddedness pada PT. BCA KCP Kapas Krampung Surabaya

\section{METODE PENELITIAN}

Studi ini dilakukan di PT. BCA KCP Kapas Krampung Surabaya, variabel penelitian terdiri dari coworker support, organizational embeddedness, dan turnover intention. Penelitian ini menerapkan metode kuantitatif dengan teknik pengambilan sampelnya menggunakan sampling jenuh dengan ukuran sampel penelitian berjumlah 40 orang yang merupakan jumlah keseluruhan karyawan di PT. BCA KCP Kapas Krampung Surabaya. Pengumpulan data menggunakan teknik wawancara serta kuesioner. Kuesioner berupa angket online menggunakan layanan Google Form, pengukuran menggunakan skala likert. Teknik analisis data, memakai Structural Equation Modeling (SEM) berbasis Partial Least Square (PLS). Pengujian terdiri dari; uji validitas, uji reliabilitas, penilaian outer model, dan penilaian inner model.

Pengukuran coworker support merujuk pada Settoon \& Mossholder (2002), dengan menggabungkan 9 -item pernyataan untuk mengetahui dukungan emosional dan instrumental karyawan. Kemudian, organizational embeddedness merujuk pada Robinson et al. (2014) yang menyebutkan indikator paling substantif dan kuat untuk mengukur organizational embeddedness adalah organizational fit, organizational sacrifice, organizational links. Selanjutnya pengukuran turnover intention merujuk pada Jung \& Yoon (2013), yang disederhanakan menjadi empat item pernyataan yaitu mempertimbangkan secara serius untuk meninggalkan organisasi, merasa terdorong untuk keluar dari perusahaan, kemungkinan mencari pekerjaan alternatif, dan keluar jika kondisi menjadi lebih buruk daripada sekarang.

\section{HASIL DAN PEMBAHASAN}

Kuesioner diberikan kepada 40 orang karyawan, namun yang dikembalikan sejumlah 32 kuesioner. Tabel 1 menyajikan hasil karakteristik dari responden penelitian ditinjau dari beberapa aspek bersamaan dengan persentase dari jumlah keseluruhan responden. Dari tabel tersebut, terlihat bahwa mayoritas responden yakni laki-laki dengan proporsi $64,7 \%$, berusia di bawah 30 tahun dengan persentase sebesar 58,8\%, memiliki latar belakang pendidikan strata satu dengan persentase sebesar $52,9 \%$, dan lama masa kerja dalam rentang waktu kurang dari lima tahun dengan persentase sebesar $55,9 \%$.

Tabel 1.

\section{KARAKTERISTIK RESPONDEN}

\begin{tabular}{llc}
\hline \multicolumn{1}{c}{ Karakteristik } & Kategori & Persentase \\
\hline Jenis kelamin & Laki-laki & $64,7 \%$ \\
Usia & Perempuan & $35,3 \%$ \\
& $<30$ tahun & $58,8 \%$ \\
& $30-40$ tahun & $11,8 \%$ \\
& $41-50$ tahun & $26,5 \%$ \\
Pendidikan akhir & $>50$ tahun & $2,9 \%$ \\
& SMA & $32,4 \%$ \\
& Diploma satu & $2,9 \%$ \\
& Diploma tiga & $11,8 \%$ \\
Lama masa kerja & Strata satu & $52,9 \%$ \\
& $<5$ tahun & $55,9 \%$ \\
& 5-10 tahun & $11,8 \%$ \\
& $11-15$ tahun & $8,8 \%$ \\
& $16-20$ tahun & $5,9 \%$ \\
& $>20$ tahun & $17,6 \%$ \\
\hline
\end{tabular}

Sumber: Output SPSS, data diolah (2021) 
Berdasarkan hasil analisis statistik deskriptif untuk menggambarkan nilai rata-rata dengan three box method, coworker support terbilang tinggi dengan nilai rata-rata variabel sebesar 4,44. Begitu pula dengan organizational embeddednes dengan nilai rata-rata variabel sebesar 4,35. Sedangkan, turnover intention tergolong rendah, dengan nilai rata-rata variabel sebesar 1,88.

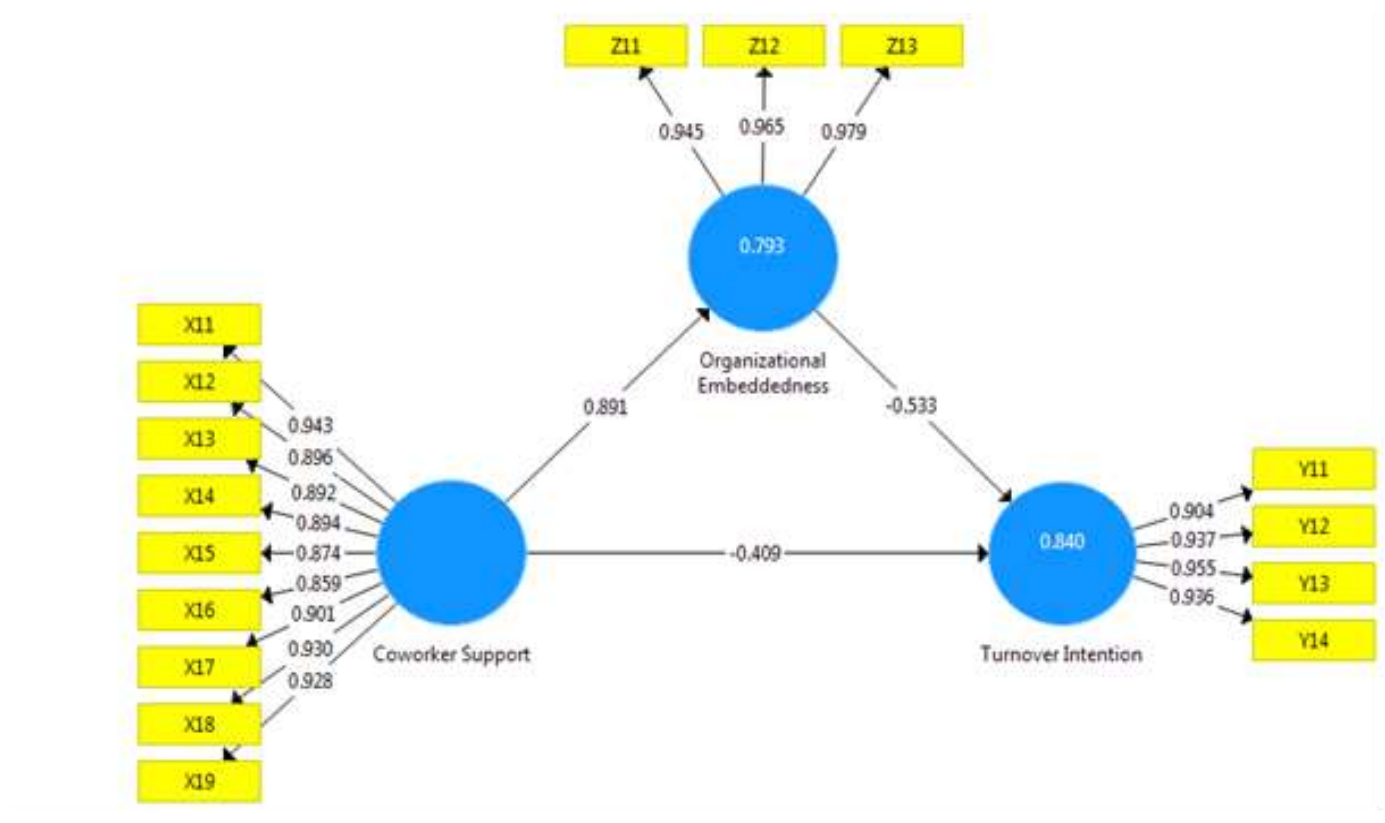

Sumber: Output SmartPLS ver. 3.3.3 (2021)

Gambar 2. HASIL UJI MEASUREMENT MODEL

Nilai outer loadings pada setiap indikator kuesioner yang menunjukkan angka lebih besar dari 0,70 dianggap validitasnya sudah baik, maka data pada gambar 1 di atas sudah memenuhi hal tersebut. Selain itu, nilai composite reliability yang lebih tinggi dari angka 0,70 memiliki reliabilitas tinggi, demikian artinya hasil uji yang tertera pada tabel 2 sudah memenuhi kriteria reliabilitas yang baik.

Besaran hasil dari cronbach's alpha mampu meningkatkan besar composite reliability apabila sebuah variabel menghasilkan nilai lebih tinggi dari 0,60, apabila ditinjau dari hasil pada tabel 2 , keseluruhan variabel telah memiliki reliabilitas yang kuat. Adapun besaran nilai $R$-Square variabel turnover intention sebesar 0,793, artinya variabel turnover intention mampu dijelaskan oleh variabel coworker support sebesar 79\%. Begitupun nilai $R$-Square variabel ogranizational embeddedness sebesar 0,840, artinya variabel konstruk ogranizational embeddedness mampu dijelaskan variabel coworker support sebesar $84 \%$, sedangkan $16 \%$ sisanya dipengaruhi variabel-variabel di luar penelitian.

Tabel 2.

COMPOSITE RELIABILITY, CRONBACH'S ALPHA, DAN R-SQUARE

\begin{tabular}{lccc}
\hline \multicolumn{1}{c}{ Variabel } & Composite Reliability & Cronbach's Alpha & R-Square \\
\hline Coworker Support & 0,975 & 0,971 & \\
Organizational Embeddedness & 0,974 & 0,961 & 0,793 \\
Turnover Intention & 0,954 & 0,951 & 0,840 \\
\hline
\end{tabular}

Sumber: Output SmartPLS ver. 3.3.3 (2021)

Tabel 3 nilai t-statistik dari pengaruh coworker support terhadap turnover intention sebesar $2,116 \geq$ 1,96 beserta nilai koefisien pengaruh langsung sebesar $-0,409$. Jadi pengaruh pada kedua variabel tersebut negatif dan signifikan. Hal tersebut mengindikasikan semakin tingginya dukungan rekan kerja yang diperoleh karyawan, maka akan semakin kecil munculnya keinginan karyawan untuk berhenti bekerja di organisasinya. 
Rahmadani Nadya Ngestreini \& Budiono Budiono. Pengaruh Coworker Support terhadap Turnover Intention melalui Organizational Embeddedness pada PT. BCA KCP Kapas Krampung Surabaya

Tabel 3.

\section{PATH COEFFICIENTS DAN INDIRECT EFFECT}

\begin{tabular}{lccc}
\hline \multicolumn{1}{c}{ Keterangan } & Origin Sample & T-Statistic & Keputusan \\
\hline Coworker Support $\rightarrow$ Turnover Intention & $-0,409$ & 2,116 & $\geq 1,96$ (Signifikan) \\
Coworker Support $\rightarrow$ Organizational Embeddedness & 0,891 & 22,025 & $\geq 1,96$ (Signifikan) \\
Organizational Embeddedness $\rightarrow$ Turnover Intention & $-0,533$ & 2,722 & $\geq 1,96$ (Signifikan) \\
Coworker Support $\rightarrow$ Organizational Embeddedness $\rightarrow$ & $-0,475$ & 2,612 & $\geq 1,96$ (Signifikan) \\
Turnover Intention
\end{tabular}

Sumber: Output SmartPLS ver. 3.3.3 (2021)

Nilai t-statistik pengaruh coworker support terhadap organizational embeddedness sebesar $22,025 \geq$ 1,96 dan koefisien pengaruh langsung sebesar 0,840, artinya terdapat pengaruh signifikan positif coworker support pada niat karyawan untuk berhenti kerja di organisasinya. Artinya, semakin baik dukungan rekan kerja yang dirasakan karyawan, maka akan semakin baik pula keterlekatan mereka terhadap organisasinya.

Selanjutnya, angka t-statistik pengaruh organizational embeddedness terhadap turnover intention bernilai $2,722 \geq 1,96$ beserta koefisien pengaruh langsung sebesar $-0,533$, artinya terdapat pengaruh signifikan negatif dari keterlekatan organisasi pada niat karyawan untuk berhenti dari pekerjaannya. Demikian artinya semakin baik keterlekatan karyawan pada organisasi, semakin kecil niat untuk keluar dari organisasi. Adapun nilai t-statistik pengaruh coworker support terhadap turnover intention melalui organizational embeddedness sebesar 2,612 $\geq 1,96$ dengan koefisien pengaruh langsung sebesar $-0,475$, artinya organizational embeddedness mampu menjadi variabel mediasi pengaruh coworker support pada niat karyawan untuk berhenti dari pekerjaan.

\section{Pengaruh Coworker Support terhadap Turnover Intention}

Hasil pengujian, coworker support memiliki pengaruh signifikan negatif pada intensi karyawan melakukan turnover. Apabila semakin tinggi coworker support yang dirasakan karyawan maka turnover intention akan semakin rendah.

Hasil ini mendukung Hmrd \& Yy (2020), ketika dukungan meningkat, turnover intention karyawan akan menurun, sehingga perusahaan perlu memerkuat hubungan antar karyawan yang kuat dengan memfokuskan sumber-sumber dukungan, yaitu: coworker support, supervisor support, dan organizational support agar karyawan tetap berada dalam perusahaan. Hasil ini relevan dengan Anisa (2019), De Clercq et al. (2020), dan Self \& Gordon (2019).

Apabila dikaitkan hasil wawancara dengan salah satu karyawan CSO di PT. BCA KCP Kapas Krampung Surabaya, rekan kerja berperan dalam memberikan dukungan baik terhadap kinerja maupun emosional, yang pada akhirnya menyebabkan berkurangnya stres yang dirasakan di tempat kerja. Memiliki dukungan dari rekan kerja yang baik membuat berkerja terasa seperti dilakukan bersama keluarga. Sehingga, akan menimbulkan rasa enggan untuk keluar dari pekerjaan dan meninggalkan "rumah kedua". Maka dapat diketahui bahwa coworker support yang dirasakan karyawan yang bekerja di PT. BCA KCP Kapas Krampung Surabaya dapat menurunkan niat karyawan untuk keluar dari pekerjaannya di PT. BCA KCP Kapas Krampung Surabaya.

\section{Pengaruh Coworker Support terhadap Organizational Embeddedness Karyawan PT. BCA KCP Kapas Krampung Surabaya \\ Hasil pengujian menunjukkan coworker support memiliki pengaruh positif dan signifikan terhadap organizational embeddedness. Artinya, apabila semakin tinggi coworker support yang dirasakan akan meningkatkan pula organizational embeddedness pada diri karyawan.}

Hasil ini mendukung Self \& Gordon (2019), di mana para pekerja yang memiliki keterlekatan tinggi pada organisasi kerjanya akan memiliki hubungan baik pula dengan rekan kerjanya, dan ketika karyawan tersebut menerima dukungan dari rekan kerja mereka, kemungkinan besar mereka tidak 
memiliki niat untuk keluar dari organisasinya. Penelitian lainnya yang sejalan dengan hasil ini yaitu Self \& Gordon (2020), Singh et al. (2017), dan Karatepe (2016).

Didukung dengan informasi dari karyawan bagian teller prioritas di PT. BCA KCP Kapas Krampung Surabaya, bekerja bersama rekan di tempat kerja terasa menyenangkan dan nyaman sehingga dapat mengurangi rasa lelah dalam pekerjaannya. Karena rasa nyaman tersebut, maka suasana kerja yang harmonis dapat tercipta. Suasana kerja yang harmonis membuat para karyawan merasa terhubung dengan organisasi, yang pada akhirnya akan membuat karyawan dengan senang hati akan bekerja keras dan senantiasa mendukung perkembangan organisasinya. Bahkan, setiap diadakan event di perusahaan, mereka dengan senang hati meluangkan waktu untuk mengerjakan suatu project di luar jam kerja. Maka dapat diketahui bahwa coworker support yang dirasakan karyawan yang bekerja di PT. BCA KCP Kapas Krampung Surabaya dapat meningkatkan organizational embeddednes karyawan di PT. BCA KCP Kapas Krampung Surabaya.

\section{Pengaruh Organizational Embeddedness terhadap Turnover Intention Karyawan PT. BCA KCP Kapas Krampung Surabaya}

Organizational embeddedness memiliki pengaruh signifikan negatif pada intensi melakukan turnover. Apabila semakin tinggi organizational embeddedness pada diri karyawan, maka intensi karyawan pada turnover akan semakin berkurang.

Hasil ini sesuai dengan Peltokorpi et al. (2014) bahwa keterlekatan karyawan dapat membantu organisasi untuk memertahankan karyawan dengan lebih baik, sehingga akan membatasi berbagai biaya yang disebabkan oleh voluntary turnover. Hasil sejenis juga dikemukakan Huang et al. (2020), Peltokorpi et al. (2014), Dechawatanapaisal (2017), Zakaria \& Astuty (2017), Rarasanti \& Suana (2016), Nguyen (2015), dan Aryani \& Rahardjo (2018).

Wawancara pada karyawan bagian teller diketahui bahwa rasa keterlekatan pada organisasi memunculkan rasa memiliki dan bergantung, banyak yang harus dikorbankan apabila meninggalkan organisasi khususnya keadaan pandemi seperti ini. Sulitnya mencari pekerjaan dan terlanjur merasa nyaman dengan orang-orang di tempat kerja menjadikan seseorang enggan untuk meninggalkan pekerjaannya. Sehingga organizational embeddedness yang ada pada karyawan yang bekerja di PT. BCA KCP Kapas Krampung Surabaya berpengaruh negatif pada niat karyawan untuk berhenti kerja.

\section{Pengaruh Coworker Support pada Turnover Intention melalui Organizational Embeddedness pada Karyawan PT. BCA KCP Kapas Krampung Surabaya}

Hasil pengujian diketahui bahwa coworker support menghasilkan direct effect terhadap turnover intention dan indirect effect melalui organizational embeddedness. Dengan demikian, organizational embeddedness dapat memediasi pengaruh antara coworker support terhadap turnover intention, sehingga $\mathrm{H} 4$ diterima. Hasil ini mendukung Huang et al. (2020) tentang bagaimana job embeddedness bertindak sebagai faktor mediator dalam peran overwork dalam turnover yang dilakukan oleh knowledge workers yang ada di Negara Cina. Riset terdahulu yang menunjukkan variabel job embeddedness sebagai mediator, dilakukan Safavi \& Karatepe (2019), Ferreira et al. (2017), dan Thakur \& Bhatnagar (2017).

Hasil ini, didukung hasil wawancara dengan karyawan bagian customer service, bahwa keterlekatan karyawan dengan organisasi menjadikan seseorang enggan meninggalkan organisasinya. Seseorang akan merasa memiliki dan bergantung pada organisasinya, sehingga memberikan pengaruh terhadap turnover intention. Dari pernyataan tersebut, diketahui bahwa ada pengaruh coworker support terhadap turnover intention yang dimediasi organizational embeddedness.

\section{KESIMPULAN}

Hasil penelitian membuktikan bahwa coworker support berpengaruh signifikan negatif pada niat karyawan untuk berhenti kerja di organisasi. Coworker support berpengaruh signifikan positif dan 
Rahmadani Nadya Ngestreini \& Budiono Budiono. Pengaruh Coworker Support terhadap Turnover Intention melalui Organizational Embeddedness pada PT. BCA KCP Kapas Krampung Surabaya

organizational embeddedness. Organizational embeddedness berpengaruh signifikan negatif pada niat karyawan untuk berhenti kerja di organisasi; dan coworker support berpengaruh signifikan negatif terhadap intensi turnover melalui organizational embeddedness.

Berdasarkan hasil penelitian, coworker support yang dirasakan karyawan termasuk kategori tinggi. Kendati demikian, salah satu item pernyataan yang menjelaskan tentang kesediaan karyawan menghibur rekan kerja saat menghadapi hari yang buruk, memperoleh skor paling rendah. Maka, manajemen perusahaan perlu menerapkan komunikasi yang baik dan penuh empati pada karyawannya. Kecerdasan emosi karyawan perlu ditingkatkan dengan motivasi rutin seperti acara gathering bersama rekan kerja dan direksi untuk mendiskusikan berbagai realitas kerja yang dialami karyawan. Selanjutnya dari sisi organizational embeddeddnes, karyawan dengan keterlekatan tinggi cenderung bersedia melakukan pekerjaan di luar jam kerja, yang berakibat turunnya kesejahteraan dalam work-life balance. Maka sebaiknya pihak manajemen mengusahakan pemberian insentif atau reward sebagai pengganti waktu yang digunakan untuk mengerjakan project agar kesejahteraan jangka panjang karyawan tetap terjaga. Dengan menjaga kesejahteraan karyawan, niat untuk keluar pun akan semakin berkurang.

Keterbatasan penelitian ini terletak pada sedikitnya jumlah sampel, dan kurang terfokus pada karyawan di bagian pekerjaan tertentu. Sehingga, rekomendasi untuk penelitian selanjutnya sebaiknya menggunakan sampel yang jumlahnya lebih besar, memfokuskan pada bagian atau departemen tertentu, atau meneliti objek dari jenis industri lainnya.

\section{DAFTAR PUSTAKA}

Anisa, J. (2019). Peran Mediasi Kepuasan Kerja dalam Hubungan Ketidakamanan Kerja dan Dukungan Rekan Kerja Terhadap Turnover Intention di Bank Bukopin Cabang Yogyakarta. Jurnal Ekonomi Dan Bisnis, 2(117-123), 17.

Aryani, R. D., \& Rahardjo, W. (2018). The Effect of Job Embeddedness and Burnout on Turnover Intention in Retail Companies. International Journal for Social Studies, 04(08), 173-182.

Ayuni, E., \& Etikariena, A. (2020). Peran Mediasi Keterlekatan Kerja pada Hubungan antara Persepsi Dukungan Organisasi dengan Perilaku Kerja Inovatif. Jurnal Psikogenesis, 8(1), 30-44. https://doi.org/10.24854/jps.v8i1.1260

Cooke, F. L., Wang, J., \& Bartram, T. (2019). Can a Supportive Workplace Impact Employee Resilience in a High Pressure Performance Environment? An Investigation of the Chinese Banking Industry. Applied Psychology, 68(4), 695-718. https://doi.org/10.1111/apps.12184

De Clercq, D., Azeem, M. U., Haq, I. U., \& Bouckenooghe, D. (2020). The stress-reducing effect of coworker support on turnover intentions: Moderation by political ineptness and despotic leadership. Journal of Business Research, 111(January), 12-24. https://doi.org/10.1016/j.jbusres.2020.01.064

Dechawatanapaisal, D. (2017). The Mediating Role of Organizational Embeddedness on The Relationship Between Quality of Work Life and Turnover: Perspectives From Healthcare Professionals. International Journal of Manpower, 34(1), 1-5. https://doi.org/10.1108/ IJM-122015-0205 Permanent

Esterlita, H. M., \& Purba, D. E. (2019). Organizational Embeddedness Dimensions' Roles in Perceived Career Opportunities: Turnover Intention of Indonesian Millennials. Proceedings of the 2nd International Conference on Intervention and Applied Psychology, 229, 847-860. https://doi.org/10.2991/iciap-18.2019.70

Ferreira, A. I., Martinez, L. F., Lamelas, J. P., \& Rodrigues, R. I. (2017). Mediation of job 
embeddedness and satisfaction in the relationship between task characteristics and turnover A. International Journal of Contemporary Hospitality Management, 29(1), 248-267. https://doi.org/10.1108/IJCHM-03-2015-0126

Ghosh, D., Sekiguchi, T., \& Gurunathan, L. (2017). Organizational embeddedness as a mediator between justice and in-role performance. Journal of Business Research, 75, 130-137. https://doi.org/10.1016/j.jbusres.2017.02.013

Gunawan, A., \& Azzahra, R. (2017). Kelekatan Kerja, Keterikatan Kerja, dan Niat Untuk Pindah Kerja. Jurnal Manajemen Dan Akuntansi, 12(1), 1-20. https://doi.org/https://doi.org/10.32534/jv.v12i1.325

Gutmann, P. (2016). Tackling Trends in 25. (https://www.mercer.com/content/dam/mercer/attachments/global/webcasts/gl-2016-webcasttalent-tackling-trends-in-turnover-mercer.pdf, diakses pada 10 Oktober 2020)

Halimah, T. N., Fathoni, A., \& Maria M Minarsih. (2016). Lingkungan Kerja Terhadap Turnover Intention Pramuniaga di Gelael Supermarket (Studi Kasus pada Gelael Superindo Kota Semarang). Journal of Management, 2(2).

Helen, D. (2014). Cari Pegawai Tak Seperti Gigit Cabe. (https://finansial.bisnis.com/read/20141113/90/272781/cari-pegawai-tak-seperti-gigit-cabe, diakses pada 9 Oktober 2020)

Hmrd, K., \& Yy, S. (2020). The Relationship Between Co-Worker Support, Supervisor Support , Organizational Support and Employee Turnover Intention of Operational Level Employees in Apparel Sector, Central Province, Sri Lanka. IJCIRAS, 2(8), 7-17.

Huang, H., Xia, X., Zhao, W., Pan, X., \& Zhou, X. (2020). Overwork, Job Embeddedness and Turnover Intention Among Chinese Knowledge Workers. Asia Pacific Journal of Human Resources. https://doi.org/10.1111/1744-7941.12272

Jung, H. S., \& Yoon, H. H. (2013). The Effects of Organizational Service Orientation on PersonOrganization Fit and Turnover Intention. Service Industries Journal, 33(1), 7-29. https://doi.org/10.1080/02642069.2011.596932

Karatepe, O. M. (2016). Does Job Embeddedness Mediate The Effects of Coworker and Family Support on Creative Performance? An Empirical Study in The Hotel Industry. Journal of Human Resources in Hospitality and Tourism, 15(2), 119-132. https://doi.org/10.1080/15332845.2016.1084852

Karatepe, O. M., \& Olugbade, O. A. (2017). The Effects of Work Social Support and Career Adaptability on Career Satisfaction and Turnover Intentions. Journal of Management and Organization, 23(3), 337-355. https://doi.org/10.1017/jmo.2016.12

Kholiq, D. A., \& Miftahuddin, M. (2017). Effect Of Job Embeddedness, Job Satisfaction, And Organizational Commitment On Employee Turnover Intention. TAZKIYA Journal of Psychology, 22(1), 27-40. https://doi.org/10.15408/tazkiya.v22i1.8154

Malik, S., \& Malik, G. (2015). Linking Social Support at Workplace with Engagement and Retention Behaviour of Generation Y Employees. Advances in Economics and Business Management (AEBM), 18(3), 271-275.

Maska, H., \& Riyanto, S. (2020). The Influence of Job Embeddedness, Salary, and Organizational Commitment against the Turnover Intention of the Employees in the Marketing Division at 
Rahmadani Nadya Ngestreini \& Budiono Budiono. Pengaruh Coworker Support terhadap Turnover Intention melalui Organizational Embeddedness pada PT. BCA KCP Kapas Krampung Surabaya

Pharmaceutical Laboratories Industry in Jabodetabek. IOSR Journal of Business and Management, 22(2), 29-35. https://doi.org/10.9790/487X-2202062935

Mathis, R. L., \& Jackson, J. H. (2011). Human Resource Management (10th ed.). Jakarta: Salemba Empat.

Naz, S., Li, C., Nisar, Q. A., Khan, M. A. S., Ahmad, N., \& Anwar, F. (2020). A Study in the Relationship Between Supportive Work Environment and Employee Retention: Role of Organizational Commitment and Person-Organization Fit as Mediators. SAGE Open, 10(2), 120. https://doi.org/10.1177/2158244020924694

Ng, T. W. H., \& Feldman, D. C. (2007). Organizational Embeddedness and Occupational Embeddedness Across Career Stages. Journal of Vocational Behavior, 70(2), 336-351. https://doi.org/10.1016/j.jvb.2006.10.002

Nguyen, V. (2015). Job Characteristics Job Embeddedness and Turnover Intention: the Case of Vietnam. Journal of International \& Interdisciplinary Business Research, 2(1), 98.

Octavia Asta Maniri, R. (2019). Analisis Pengaruh Job Embeddedness Dan Kepuasan Kerja Terhadap Turnover Intention Pada PT. Purnama Indonesia. Jurnal Ilmu Manajemen (JIM), 7(2), 430-436.

Peltokorpi, V., Allen, D. G., \& Froese, F. (2014). Organizational Embeddedness, Turnover Intentions, and Voluntary Turnover: The Moderating Effects of Employee Demographic Characteristics and Value Orientations. Journal of Marriage and Family, 60(1), 5-22. https://doi.org/10.1002/job

Prahadi, Y. Y. (2015). Turnover Talent Tinggi, Ini Dia Pemicunya. 2020, 10-12. (https://swa.co.id/swa/trends/management/turnover-talent-tinggi-ini-dia-pemicunya-survei, diakses pada 10 Oktober 2020)

Rarasanti, I. A. P., \& Suana, I. W. (2016). Pengaruh Job Embeddedness Kepuasan Kerja dan Komitmen Organisasional Terhadap Turnover Intention Karyawan. Jurnal Manajemen Unud, 5(7), 4690-4718.

Robinson, R. N. S., Kralj, A., Solnet, D. J., Goh, E., \& Callan, V. (2014). Thinking Job Embeddedness Not Turnover: Towards A Better Understanding of Frontline Hotel Worker Retention. International Journal of Hospitality Management, 36, 101-109. https://doi.org/10.1016/j.ijhm.2013.08.008

Safavi, H. P., \& Karatepe, O. M. (2019). The Effect of Job Insecurity on Employees' Job Outcomes: The Mediating Role of Job Embeddedness. Journal of Management Development, 38(4), 288297. https://doi.org/10.1108/JMD-01-2018-0004

Sari, F. (2020). Banyak karyawan resign, klaim BPJamsostek tembus Rp 7,6 triliun pada kuartal I2020. https://keuangan.kontan.co.id/news/banyak-karyawan-resign-klaim-bpjamsostek-tembusrp-76-triliun-pada-kuartal-i-2020, diakses pada 11 Oktober 2020)

Self, T. T., \& Gordon, S. (2019). The Impact of Coworker Support and Organizational Embeddedness on Turnover Intention Among Restaurant Employees. Journal of Human Resources in Hospitality and Tourism, 18(3), 394-423. https://doi.org/10.1080/15332845.2019.1599789

Self, T. T., Gordon, S., \& Ghosh, A. (2020). Increasing Management Retention: The Mediating Role of Organizational Embeddedness on Coworker Support and Turnover Intention. International Journal of Hospitality and Tourism Administration, 00(00), 1-19. https://doi.org/10.1080/15256480.2019.1708224 
Settoon, R. P., \& Mossholder, K. W. (2002). Relationship Quality and Relationship Context as Antecedents of Person- and Task-Focused Interpersonal Citizenship Behavior. Journal of Applied Psychology, 87(2), 255-267. https://doi.org/10.1037/0021-9010.87.2.255

Singh, B., Shaffer, M. A., \& Selvarajan, T. T. (2017). Antecedents of Organizational and Community Embeddedness: The Roles of Support Psychological Safety and Need To Belong. Journal of Organizational Behavior, 39(3), 339-354. https://doi.org/10.1002/job.2223

Suyono, J., Eliyana, A., \& Ratmawati, D. (2020). The Nightmare of Turnover Intention for Companies in Indonesia. Opcion, 36(91), 871-888.

Takase, M. (2010). A Concept Analysis of Turnover Intention: Implications for Nursing Management. Collegian, 17(1), 3-12. https://doi.org/10.1016/j.colegn.2009.05.001

Tews, M. J., Michel, J. W., \& Ellingson, J. E. (2013). The Impact of Coworker Support on Employee Turnover in the Hospitality Industry. Group and Organization Management, 38(5), 630-653. https://doi.org/10.1177/1059601113503039

Tews, M. J., Michel, J. W., \& Stafford, K. (2018). Abusive Coworker Treatment, Coworker Support, and Employee Turnover. Journal of Leadership and Organizational Studies, 26(4), 413-423. https://doi.org/10.1177/1548051818781812

Tews, M. J., Michel, J. W., \& Stafford, K. (2019). Social Support and Turnover Among Entry-Level Service Employees: Differentiating Type, Source, and Basis of Attachment. Human Resource Management, 59(3), 221-234. https://doi.org/10.1002/hrm.21989

Thakur, S. J., \& Bhatnagar, J. (2017). Mediator Analysis of Job Embeddedness: Relationship between work-life balance practices and turnover intentions. Employee Relations: The International Journal, 1-27. https://doi.org/https://doi.org/10.1108/ER-11-2016-0223

Tri Wijayati, D., Fazlurrahman, H., Kholidi Hadi, H., Rahman, Z., \& Kautsar, A. (2020). Coaching As Determinant of Job Performance: Co-working Support As Mediating Variable. KnE Social Sciences, 2020(2015), 240-250. https://doi.org/10.18502/kss.v4i7.6855

Umboh, J. J. (2015). The Influence Of Organizational Socialization On Employee Turnover Intention. Jurnal EMBA, 3(1), 107-116.

Williams, S. E. (2018). Organizational Culture, Supervision and Retention of Public Child Welfare Workers. Journal of Sociology and Social Work, 6(2), 1-5. https://doi.org/10.15640/jssw.v6n2a1

Wongboonsin, K., Dejprasertsri, P., Krabuanrat, T., Roongrerngsuke, S., Srivannaboon, S., \& Phiromswad, P. (2018). Sustaining Employees Through Co-worker and Supervisor Support: Evidence From Thailand. Asian Journal of Business and Accounting, 11(2), 187-214. https://doi.org/10.22452/ajba.vol11no2.6

Woo, B., \& Chelladurai, P. (2012). Dynamics of Perceived Support and Work Attitudes: The Case of Fitness Club Employees. Human Resource Management Research, 2012(1), 6-18. https://doi.org/10.5923/j.hrmr.20120201.02

Zainuddin, Y., \& Noor, A. (2019). The Role of Job Embeddedness and Organizational Continuance Commitment on Intention to Stay: Development of Research Framework and Hypotheses. KnE Social Sciences, 2019, 1017-1035. https://doi.org/10.18502/kss.v3i22.5108

Zakaria, R., \& Astuty, I. (2017). Pengaruh Kompensasi Terhadap Turnover Intention Dengan Job Embeddedness Sebagai Variabel Intervening. Jurnal Manajemen Bisnis, 8(1), 82-97. 
Rahmadani Nadya Ngestreini \& Budiono Budiono. Pengaruh Coworker Support terhadap Turnover Intention melalui Organizational Embeddedness pada PT. BCA KCP Kapas Krampung Surabaya

https://journal.umy.ac.id/index.php/mb/article/view/3928/3387

Zhang, M., Fried, D. D., \& Griffeth, R. W. (2012). A Review of Job Embeddedness: Conceptual, Measurement Issues, and Directions for Future Research. Human Resource Management Review, 22(3), 220-231. https://doi.org/10.1016/j.hrmr.2012.02.004 